\section{The so-called South Plant of Egyptian Art}

THE identification of the original source of any conventionalised artistic form is always, I think, worth notice. It will probably interest many readers of NATURE to draw their attention to a short but instructive piece of work of this kind which Prof. Julius Lange has communicated to the Royal Academy of Copenhagen (Bull., I884, pp. Io9-I I4). I am indebted to Mr. Liden, one of our garden staff at Kew, for a translation of the paper from the original Danish. I have freely condensed the details.

There is a well-known Egyptian symboliwwich represents both Northern and Southern Egypt. The northern symbol is admitted to represent the stem and head of the Papyrus. But the southern symbol has not hitherto been identified with any certainty. It has a lily-like form, and has been generally referred to the Lotus (Nymphcea), an identification which Prof. Lange thinks quite inadmissible, as the conventionalised treatment of this plant in Egyptian art is quite different.

The twin-symbol combining in a kind of knot the north and south plants is commonly found inscribed on the thrones of statues of Egyptian kings. In the later examples the south plant has the form of a flower with three divisions of the perianth depicted (implying that it was either five- or six-parted), and a definite flower-stalk. In one case Prof. Lange met with an example where the flower was separated from its stalk by some transverse carved lines.

Prof. Lange has, however, recently examined a diorite statue of King Chefren, which gives the symbol in a more primitive form. He finds that the supposed flower passes imperceptibly into the stalk, and that the apparent perianth segments are really distinct parts which are ticd together by indications of ligatures. Without then arriving at any definite conclusion, he is content to point out the resemblance of the south symbol in this form to the palm-capitals of the Ptolemaic period. In these the leaves of the date are disposed round the body of the capital, and the junction of this with the column is indicated by transverse bands, the conventional representations of the ligatures which would hold the leaves together and in their places. As the date, according to Alphonse de Canclolle ("L'Origine des Plantes cultivées," p. 240) has existed from prehistoric times in the dry and hot zone from Senegal to the basin of the Indus, between lat. $15^{\circ}$ and $30^{\circ}$, a more characteristic plant as the symbol of Southern Egypt can harlly have been pitched upon.

\section{W. T. THISEl'TON DYeR}

\section{Earthworms}

I SEE, in your issue of October 9 (vol. xxx. p. 570), an interesting communication entitled "A Gigantic Earthworm," in which the writer refers to worms of large size being fairly common in parts of Cape Colony. I may mention that here in Ceylon it is not an infrequent sight to see two or three of these big worms in the same day, after showers, though I would not pronounce them to be exactly common. I have seen some fully four feet in length, and about the thickness of one's little finger. They are of a pale slaty bluish colour, and appear, on close examination, to have faint prismatic colours over parts of the body. These worms are scemingly not confined to particular soils or altitudes, as I have met with them at elevations of from 2000 to 4000 fect above the sea. Owing to their seeming inertness of body, the lob-worms-as I have frequently heard them called-soon fall an easy prey to swarms of small red and black ants, that attack the victim as it lies on the ground.

Passing from large to small, I may mention a curious earthworm that I found to be very common in North Borneo. "The chief peculiarity about this worm is the size of its "cast," this being about four inches high by one inch and a half across the top, which is made cup-shaped or with a marked depression, for the purpose, I believe, of catching water. The stem-if I may apply the word-of the "cast" is about an inch in diameter, strongly built of rows of earthy matter laid circumferentially, widening towards the top into a lip that forms the side of the cup. Sometimes a leaf may have fallen on the "cast" in the course of erection, and this is at once built over, so that part of the "cast" may be seen above and part below. The worm itself is very small, and hard to secure. I have found the only method of catching them was to suddenly break off a fresh "cast," when one could get a glance of the worm as it rapidly withdrew into the ground. It is of a fleshy red colour, and about the thickness of the stem of a crow-quill pen, but I do not know how long, as I never succeeded in extracting a whole worm from its burrow. The "casts" are very numerous, and weigh, I should think, quite an ounce each, and are to be met with both in the forcst-as well as in gardens-and cultivated land. I also found them close to the banks of rivers that were sufficiently near the sea to be considerably impregnated with salt, so that I conclude from this that salt water is not destruc tive, at least to this species.

Bogawantalawa, Ceylon, November 5

\section{Injuries caused by Lightning in Africa}

IT is a remarkable fact that in all the publications relating to Africa we so seldom come across accounts of injuries caused by lightning. Some travellers-those of the German Loango Expedition of I $873-76$ for example-even distinctly report that, notwithstanding the extreme frequency of lightning in Africa, cases of damage inflicted by it are almost unheard of. During my own stay on the Congo, though I was eagerly on the lookout for instances of this kind, I did not succeed in authenticating a single case of injury due to the electric fluid. There was indeed a vague rumour among the natives of a man in some village having been struck dead and a "tshimbek" burnt down by lightning, but I could find no eye-witnesses of the fact ; and all the time I was in Africa I never saw a tree or other object which showed any signs of having been struck by lightning. The only case of which I obtained any authentic report $\mathrm{u}$ as that the coal-magazine of the French factory at Banana was burnt down in consequence of a lightning-stroke in March I882. I have been recently informed, however, that just a year after the destruction of the French coal-magazine, the large gin-store of the Dutch factory at Banana was similarly destroyed, a flash of lightning having kindled a great fire there which lasted four days. As a result of these two accidents following so close on one another in the same locality, lightning-conductors are now being set up at Banana, and the International Association of the Congo has had ccnductors fixed on all the magazines at Vivi.

I find in Dr. Pogge's journals, which I am now preparing for publication, an instance, witnessed by that traveller himself, of a man being killed by lightning. As far as my own researches go, I find scarcely any literature concerning the use of lightningrods or the frequency of accidents from lightning in the tropics; and if any of your readers would communicate to the columns of NATURE any information relating to this subjcct which they may have gained by a residence in those regions, they would render a great service to meteorological science.

Hamburg, November 29

VON DAXCKEIMAN

\section{The Northernmost Extremity of Europe}

Your correspondent, Mr. Mattieu Williams, says, on p. 54 that Tön berg "is admitted by all as a high authority" on Nor way. May I be permitted to ask who these "all" are? I knew this gentleman very well, and he never claimed the lea:t geos raphical authority for a faulty ant crude "Giuide for Tourists," which is all that his work is. I beg to refer your correspondent to the preface, where the author himself says that, for reasons explained, it has many faults. 'T'o set Tönsberg up as a geographical authority would indeed be an insult to Norwegian geographers. Your correspondent further says that he saw with his own eycs, ten years ago, that Knivsl jærodden jutted further north than the North Cape. Had I happened to meet him before he started on his excursion, I, then but a schoolboy, could have informed him of this startling fact. What I said was, that we had assumed it, but it had only been proved by measurements this summer. That was all. As regards the height of the promontories on the coast of Arctic Norway, I am sorry to have to repeat my contradiction that there is no single one which is higher than the North Cape. Your correspondent again quotes Tönsberg. If quoting this "high authority" at all, the statement should be correct. Your readers are informed that this guide-book says that Sværholtklubben " is izeenty.four Norwegian (why Nor:k? if Norwegian it should be Norske) feet higher than the North Cape." Tönsberg says nothing of the kind. What he says is simply that it is ufreards of (litnved') 1000 feet, and from this vague guess your correspondent evolves a fresh discovery and figures. Had he taken the trouble to consult the poorest of our geographies, he would have learned that the North Cape is indisputably the highest headland in Finmarken. His concluding statement that there are a dozen others is merely an imaginative one. 